\title{
Course Of Making Coffee Skin Bricket To The Community In Bener Meriah Village
}

\author{
Rahma $^{1}$ Nanda Safarati ${ }^{1}$ Fatimah $^{1}$ M. Taufiq ${ }^{1}$ Marnita $^{1}$ \\ ${ }^{1}$ Almuslim University, Indonesia
}

\section{ARTICLE INFO}

Article history:

Received: January 2020

Accepted: May 2020

Published: July 2020

\section{ABSTRACT}

Whereas residents can still exploit the potential of other natural resources wasted in the village. One of them is coffee skin waste. Through this activity, the team provided training and mentoring to the people of BenerMeriah Village to be able to utilize coffee skins into coffee skin briquettes as alternative fuels. Training activities and assistance in making coffee skin briquettes to the community are carried out through certain stages. Conduct counseling about empowering coffee skin waste into coffee skin briquettes, followed by making coffee sk in briquettes together. From the results of the dedication, it was obtained that the community was able to utilize coffee sk in waste as an alternative fuel.

Keywords:

Training and assistance;

Coffee skin briquettes;

Bener Meriah

How to cite: Rahma, Safarati, N., Fatimah, M. Taufiq, \& Marnita. (2020). Course Of Making Coffee Skin Bricket to The Community in Bener Meriah Village. Jurnal Pem$\begin{array}{lllll}\text { berdayaan Masyarakat Madani (JPMM), } & 4(1), & 122-128 .\end{array}$ https://doi.org/10.21009/JPMM.004.1.10 


\section{INTRODUCTION}

\section{Situation Analysis}

With the development of science and technology (science and technology) and followed by an increase in the number of inhabitants who occupy a fixed space for life, so that the need for world energy sources is increasing, especially in developing countries require a lot of energy sources to improve their living standards, while energy reserves such as oil earth, and natural gas available in the bowels of the earth is running low, therefore we are required to think of alternative energy sources that can be developed.

One alternative energy source that has not yet been developed and which has been wasted so far, namely the utilization of coffee skin waste that is processed into briquettes, because so far the use of coffee skin is only as a plant fertilizer, goat feed and has not been used optimally, to support energy needs long-term reliable and developed, while the availability of coffee is quite abundant in Indonesia, especially in Air Putih Baru Village, Curup Selatan Sub-district, Rejang Lebong District.

Coffee, which is a type of beverage, is usually served and is prepared from roasted/ roasted beans. And it tastes very delicious. in various regions in Indonesia.

Given because of the process of making coffee will produce 65 percent of coffee beans that still conta in water content and 35 percent of coffee skin waste. The coffee beans are then dried in an oven to remove the water content. and the result is 31 percent oven-dried coffee beans, which will be ground to produce 21 percent ground coffee. While the remaining 10 percent is in the form of skin waste.

Piles of mounting coffee shell waste are often found in several coffee mills. The waste is considered garbage. When it is too much, the coffee shell waste is burned. Lately, coffee shell waste is used by farmers as fertilizer. Even though the waste has been transported by farmers, the waste turns out to be inexhaustible. Besides as coffee skin, fertilizer can be used as a briquette material alternative energy to substitute kerosene and gas. By making briquettes from this coffee skin, the accumulated waste can be reduced.

Bener Meriah Village with an area of \pm $1941.61 \mathrm{~km}^{2}$ consists of 10 districts, one of them is Pinto Rime Gayo Subdistrict, Bener Meriah Regency with a population of 10,935 people originating from the Gayo tribe, $\mathrm{Pa}$ dang tribe, Aceh tribe, Javanese tribe, over time these tribes have mixed to build A more advanced village. The village of Bener Meriah is a Gayo Plateau or foreigners call it a miniature inland Europeans, with a background of coffee plantations and pine forests.

The residents of Bener Meriah Village are generally farmers, where the main commodities are gayo coffee, avocado, oil palm, cocoa, coconut, patchouli, and horticultural crops (chilies, cabbage, potatoes, and vegetables). The distance from the village of Bener Meriah to the center of the subdistrict must pass through the condition of the roads that go up and down, some of the 
unpaved roads are only in the form of large rocks which are very dangerous, especially for motorcycle riders. The sporadic distribution of hamlets and residents with natural obstacles without good road infrastructure makes the population live in difficulties in fulfilling a decent modern life. For transportation, they generally use motorbikes even with very high risks. Large rocky roads and slippery mud in the rainy season with a slope and the edge of a deep ravine is a challenge for the region that has a very beautiful natural scenery.

To cook the locals use firewood with a traditional two-hole brick design that is covered with earth or cement. My furnace like this is very fuel-efficient because heat from burn-

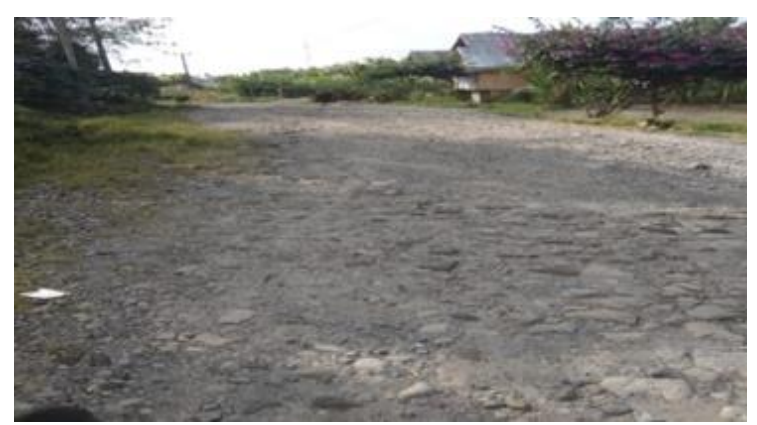

Figure 1.1

Road conditions that must be traveled to get to the village of Bener Meriah. ing spreads everywhere and is also absorbed by the stove. Firewood is obtained from plantations in the form of dry branches. With the increase in population, the need for firewood naturally increases, so it is feared that the population will loot the forest to collect wood illegally. In the rainy season, twigs and wood tend to be wet so it is not easy to burn. Some residents already provide fuelwood reserves, while others prepare LPG gas stoves. However, LPG must be imported from the subdistrict city and requires additional costs related to transportation, so the problem of supplying energy for daily cooking needs in this village is a fundamental and urgent need. As can see in Figure 1. 1, Figure 1. 2, Figure

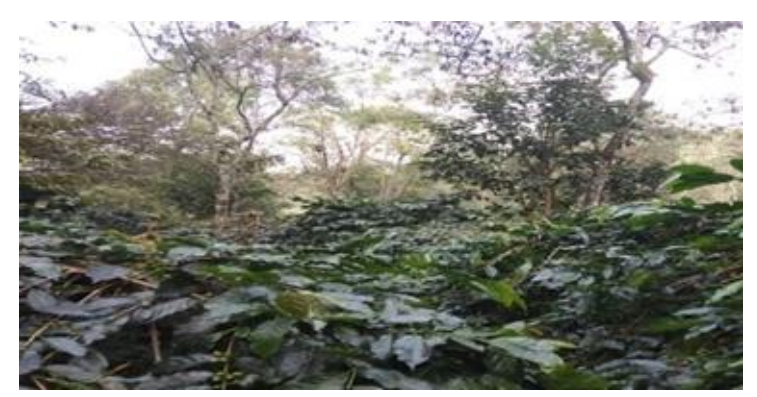

Figure 1.2

Coffee plantations are generally owned by the residents of Bener Meriah Village. 
1.3, and Figure 1. 4.

On the other hand from direct observations in general, disposing of organic agricultural waste such as coffee skins, this waste is very abundant and damages the environment when it rots and pollutes river water when it is discharged into the river. Based on the results of discussions with the village head and our community leaders from the FKIP Pend team. The Physics of Al Muslim University requested the activity of making briquettes from coffee skins. The aim is to overcome the debate about fulfilling daily alternative energy for cooking and overcoming the problem of an abundance of coffee skin waste at harvest through the introduction of appropriate technology for charcoal briquettes from coffee bean shells and simple furnaces fueled with coffee bean charcoal briquettes.

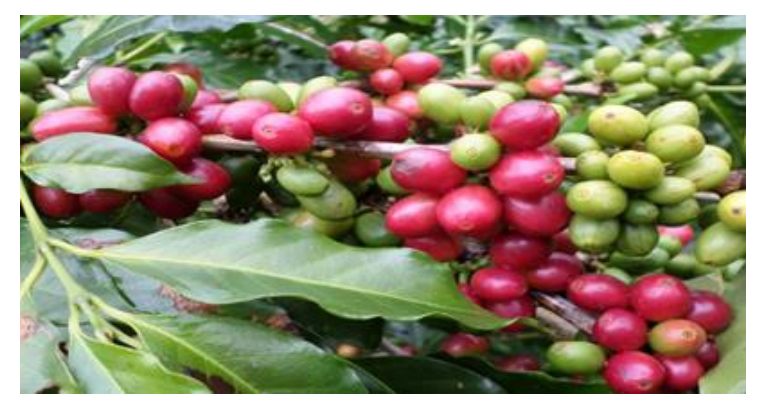

Figure 1.3

Coffee fruit that is ready to be harvested.

\section{LITERATURE REVIEW}

\section{Briquettes}

Briquette is a material that can be burned and can be used as fuel. The most commonly used briquettes are coal briquettes, charcoal briquettes, peat briquettes, and biomass briquettes. Briquette raw material is known to be close to the agricultural community because the biomass of agricultural waste can be used as briquettes. The use of briquettes, especially briquettes produced from biomass, can replace the use of fossil fuels. Biomass briquette is a waste that comes from nature that can be used directly or indirectly as a fuel source.

Compared to fossil fuels, biomass briquettes have low total greenhouse gas emissions because the ir components are part of the short carbon cycle. In addition to suppressing

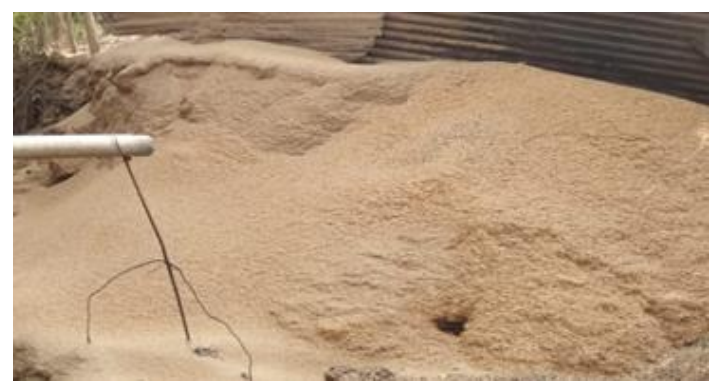

Figure 1.4

Coffee skin was te which is usually wasted. 
biomass waste to a solid size, biomass briquettes are also made by drying, carbonizing, and pyrolysis so that they can produce higher energy. Making a cavity in the center of the briquette can cause the surface area of the briquette to be greater so that the burning rate is higher.

\section{Coffe e Skin}

Coffee is one of the producers of Indonesia's foreign-exchange and plays an important role in the development of the plantation industry such as cocoa and tea. Besides having an important role as a source of foreign exchange, coffee is also a source of income for one and a half million people of coffee farmers in Indonesia.

Coffee production in Indonesia reached 739,005 tons with a plantation area of $1,254,382 \mathrm{Ha}$ in 2015. In $1 \mathrm{Ha}$ the coffee plantation area will produce about 1.8 tons of fresh waste but the resulting coffee waste is still not optimally utilized and allowed to pile up so that it becomes the wrong one cause of environmental pollution. Therefore, coffee husks can be used as a mixture of briquettes with the basic ingredients of rice husks, which have a high heating value, low water content, and low sulfur content.

\section{MATERIAL AND METHOD}

\section{Identification of proble ms}

The limited fuel that can be utilized by the community to meet their daily needs. And the abundance of coffee skin waste that pollutes the community's environment.

\section{Requirements Analys is}

Many potential natural resources are just wasted in the village of Bener Meriah during the harvest season. One of them is coffee bean skin waste which is very abundant and disrupts the environment when it rots and pollutes river water when the waste is discharged into the river. Coffee waste can be utilized as an alternative fuel, this has become something new for the people of Bener Meriah Village.

Tools and Materials Required in making coffee skin briquettes, namely:

a. Coffee fruit skin that has been separated from coffee beans

b. Sawdust wood/straw

c. Adhesives or the like which can glue the two materials together
d. Furnace
e. Briquette maker
f. Sifter
g. Stove if needed
h. Water

\section{Method}

The methods and steps used in making coffee skin briquettes are:

1. Submit a request to the village head

2. Conduct discussions with village officials

3. Socializing activities with village officials and the local community

4. Provide the tools and materials needed 
5. Training program for making coffee skin briquettes

6. Evaluating activities

This method is carried out so that the program implementation team can carry out activities smoothly. with the help of village officials and the local community, and can add insight into the local village community.

\section{RESULT AND DISCUSSION SERVICE RESULTS}

\section{Result}

The results achieved in this service include:

1. The community is very enthusiastic in participating in the training to make coffee leather charcoal briquettes, visible from the work produced during the training.

2. The community can use and utilize coffee skin charcoal briquettes.

\section{Discussion Service Results}

The coffee briquette training went well and smoothly. this is because the enthusiasm of the community is very large. During the activity, both young and adult participants, men and women were very eager to listen to the socialization and also participated in the activity.

Based on the results of monitoring from this training, the community has understood and has used coffee skin waste into briquettes. This is also a big advantage for them, given the limitations and scarcity of LPG as fuel. also, the environment where there used to be scattered coffee coolies, and piles of coffee skins were no longer vis ible.

\section{CONCLUSIONS AND RECOMMENDATION}

The conclusions of this community service activity are:

1. Almuslim University as a higher education institution has succeeded in sharing knowledge and technology to help solve problems in its environment by utilizing local resources.

2. The people of the village get new skills in utilizing waste that has abundant potential to be converted into charcoal briquettes which can be used as alternative energy to reduce the cost of daily fuel consumption.

3. The training provided to the true merry village community can change the mindset of the community about utilizing energy to meet their daily needs can be met by changing the coffee bean shells that are all as rubbish into alternative energy sources for them.

4. Communities can take advantage of waste that pollutes their environment and turn it into charcoal briquettes that have the potential to increase income if they are diligent and observant in seeing opportunities.

\section{REFERENCES}

Affandi, Komala A, dkk. 2018. Analisa Ukuran Butir Briket Campuran 
Sekam Padi dengan Cangkang Kopi Terhadap Laju Pembakaran dan Emisi Karbon Monoksida (CO). Jurnal Material dan Energi Indonesia. Vol. 08. No. 01 (2018). Pp. 44-48.

Apriani Ajeng. 2008 .Pemanfaatan Sampah

Organik Sebagai Briket. Tugas Akhir Jurusan Teknik Lingkungan ITS Surabaya.

Budiawan, Lucky., dkk. 2014. Pembuatan dan Karakterisasi Briket Bioarang dengan Variasi Komposisi Kulit Kopi. Jurnal Bioproses Komoditas Tropis. Vol.2 No.2, Nopember 2014.

Buku Panduan Pengabdian Kepada Masyarakat. Bireuen: Universitas Almuslim.

Fitri, Nusyah. 2017. Pembuatan Briket dari Campuran Kulit Kopi (Coffea Arabica) dan Serbuk Gergaji dengan Menggunakan Getah Pinus (Pinus Merkusii) Sebagai Perekat. Skripsi: Jurusan Kimia Fakultas Sains dan Teknologi UIN A lauuddin Makassar.

Getisari,Melina.,dkk. 2013. Labubadak (Pelatihan Pembuatan Briket Arang dari Kulit Salak) Sebagai Energi Alternatif dan Bernilai Ekonomis di Desa Sekura. Universitas Muhammaddiyah Pontianak.

Maidah, Nurul \& Kartini, Titin. 2015. Pemberdayaan Masyarakat Miskin Melalui Pemanfaatan Limbah Kulit Kopi Robusta Menjadi Briket (Studi Kasus Pada Ibu Rumah Tangga Di Desa Harjomulyo Kecamatan Silo Kabupaten Jember). Jurnal Pendidikan Ekonomi,
Edisi IX No.2, Mei 2015, Hal, 79-90.

Novety Citria. 2008. Perancangan Kompor Hemat Energi Dengan Bahan Bakar Briket Biomass. Jurusan Teknik Fisika. ITS: Surabaya

S. Yokoyama. 2008. Buku Panduan

Biomassa Asia: Panduan untuk Produksi dan Pemanfaatan Biomassa. Jepang: The apan Institute of Energy.

Suloi, Andi Nur Fajri. 2019. Pemanfaatan Limbah Kulit Kopi sebagai Upaya Pemberdayaan Ibu-Ibu Rumah Tangga di Desa Latimojong Kabupaten Enrekang. Jurnal Ilmiah Pengabdian Kepada Masyarakat. Vol. 5 (3): 246-250.

Wulan, et.al. 2004. Bahan Bakar dan Pembakaran. Website: www.ui.ac.id. Akses 29 Agustus 2013 